\title{
Regulatory genes in the thermoregulation of Escherichia coli pili gene transcription
}

\author{
Mikael Göransson, Kristina Forsman, and Bernt Eric Uhlin' \\ Department of Microbiology, University of Umeå, S-901 87 Umeå, Sweden
}

\begin{abstract}
Expression of several different pilus adhesins by Escherichia coli is subject to thermoregulation. The surfacelocated fimbrial structures are present during growth at $37^{\circ} \mathrm{C}$ but are not produced by cells grown at lower temperatures, such as $25^{\circ} \mathrm{C}$. As a step toward understanding the molecular mechanism, we have studied the role of different cistrons of a cloned pilus adhesin gene cluster (pap) from a uropathogenic $E$. coli isolate. By promoter cloning, mRNA analysis, and expression of subcloned genes in trans, we have identified the papI gene as the mediator of thermoregulation at the level of pilus adhesin gene transcription. Expression of the major pilus subunit gene (papA) and several other pilus protein cistrons appeared to be dependent on stimulation by the papB and papI gene products. Constructs carrying different pap DNA regions indicated that none of the known Pap proteins acts directly as thermosensor. The chromosomal rpoH gene and $\mathrm{RpoH} \sigma$ factor did not appear to be required for pap transcription, and the thermoregulation of pilus gene transcription must be different from that of the heat shock regulon. By overexpressing the papI gene product from an expression plasmid in trans, we could circumvent the temperature regulation and turn on production of pilus adhesin at low temperature. Our results suggest that the level of mRNA encoding the PapI activator is limiting at low growth temperatures and that thermoregulation is due to a determinant in the papI-papB intercistronic region.
\end{abstract}

[Key Words: Adhesion genes; environmental regulation; thermoregulated mRNA synthesis; transcription activation; regulatory networks]

Received August 8, 1988; revised version accepted October 31, 1988.

Microorganisms presumably multiply as rapidly as environmental conditions permit. Studies of enteric bacteria such as Escherichia coli and Salmonella typhimurium show that they have evolved mechanisms that permit rapid growth under favorable conditions and aid in survival under conditions that are unfavorable for growth (Neidhardt 1987). Changes in the growth conditions may therefore cause more or less complex alterations in the biochemistry and properties of the cells. Regulatory networks such as the heat shock regulon, the SOS regulon, and the CAMP-CRP regulon are examples of how multigene systems may be affected coordinately by changes in environmental conditions. In addition to the networks and regulons that most bacteria seem to possess, one may find that individual isolates can express special properties lacking in the majority of a given species. The ability to adhere to surfaces in the surroundings is an example of such a property, and this kind of interaction between the microorganism and the environment is particularly important and evident in the case of infectious disease (Ofek and Beachey 1980). Adhesion by E. coli to human epithelial cells, as exemplified in the case of uropathogenic isolates, is commonly mediated by receptorspecific pilus adhesins (Korhonen et al. 1982; Svenson et al. 1983). The appearance of pili on the bacteria and ex-

\footnotetext{
${ }^{1}$ Corresponding author.
}

pression of adhesive properties correlating to virulence are often temperature dependent, with optimum at $37^{\circ} \mathrm{C}$ and reduced at lower temperatures (De Graaf et al. 1980; Göransson and Uhlin 1984). Other conditional factors, e.g., growth substrate, may also influence the expression of pilus adhesins, and it appears that regulatory mechanisms have evolved to allow for successful colonization of a given niche under appropriate environmental conditions (Silverman et al. 1984).

Analysis of the molecular mechanism(s) involved in thermoregulation of adhesion should increase our knowledge about how external stimuli are transmitted to the level of gene expression. Molecular genetic studies of several determinants of pilus adhesins in $E$. coli have shown that there are multicistronic gene clusters encoding the different major and minor pilus proteins and the biogenesis of these surface organelles (for reviews, see Mooi and de Graaf 1985; Uhlin et al. 1985b; Normark et al. 1986). Using gene operon fusions to $l a c Z$, we obtained evidence suggesting that the temperature regulation of digalactoside-binding pili (Pap pili) expression operates at the level of transcription of at least the major pilin gene, papA (Göransson and Uhlin 1984). Subsequent analysis established that there are two cistrons in the region upstream of papA (papB and $p a p I \mid$, that $p a p A$ is cotranscribed with $p a p B$, and that $p a p B$ and $p a p I$ seem to be involved in regulation of $p a p A$ expression (Båda et al. 1985, 1988; see also Fig. 1). We 
have studied the role of different pap cistrons in the temperature regulation of pilus production and expression of the adhesion properties.

\section{Results}

Thermoregulation of Pap pilus adhesin is mediated by the papI-papB region

In addition to the major pilin subunit gene, papA, the formation of pilus adhesin involves several accessory genes and minor pilus protein genes (i.e., papC-papH, Fig. 1). Most distal from papA is the $p a p G$ gene, and it has been shown to encode the pilus protein, which is responsible for the binding specificity of the Pap adhesin (Lund et al. 1987). The papA gene is part of an operon starting with $p a p B$, and although most transcripts seem to terminate between $p a p A$ and $p a p H$, there is evidence that some transcription continues through the papH-
papC region and perhaps even farther (Båga et al. 1985 1987, 1988; Uhlin et al. 1985a). Therefore we asked whether or not expression of all genes required for biogenesis of pili and adhesin was dependent on the regulatory genes and sequences located upstream of papA. One way to test this was to determine whether pilus production and expression of adhesin could be made constitutive at both high and low temperatures if the region upstream of papA were replaced by DNA sequences encoding a temperature-independent promoter region. Our studies with the $E$. coli alaS gene promoter suggested that it would be suitable, considering the relative strength and apparent temperature independence of that promoter upon cloning into operon fusion vectors ( $\mathrm{Sjö-}$ berg et al. 1986, and unpubl.; see also Table 2). The plasmid pHMG93 contains all of the pap genes required for production of pili and adhesin, whereas the region including papI and part of the papB gene has been replaced by DNA encoding the $5^{\prime}$ end and the promoter of

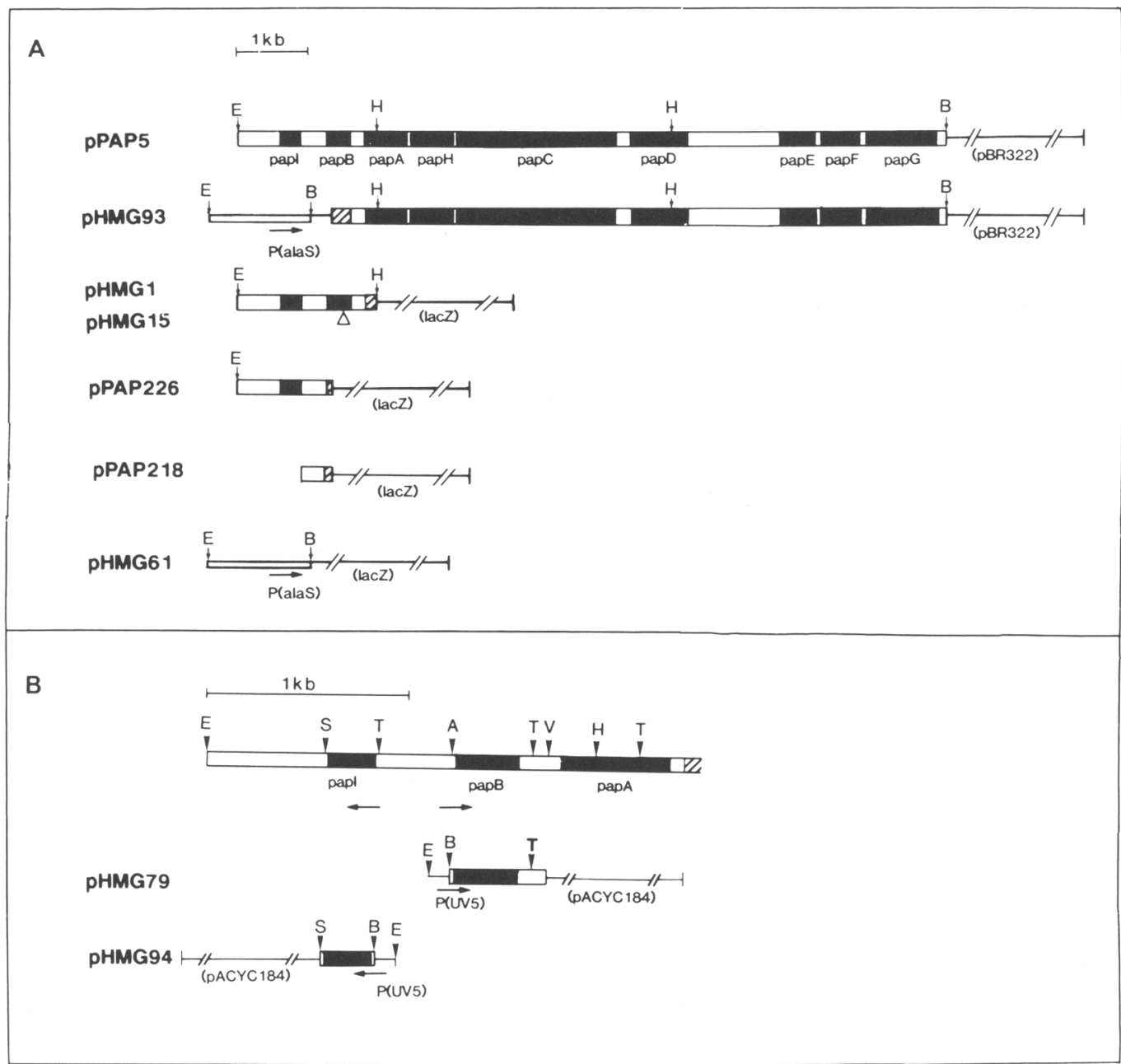

Figure 1. Genetic and physical maps of plasmids: $(A)$ Constructs expressing Pap pilus-adhesin genes or lac $Z$ operon fusions; $(B \mid$ PapB and PapI overproducing plasmids are shown below a map of the papI-papB-papA region. The parts representing cloning vector DNA are indicated by interrupted lines and are not drawn to scale. The filled parts of the bars show the coding regions of the indicated pap genes. Hatched portions show that only a part of a gene is remaining. Vertical arrowheads indicate cleavage sites for different restriction endonucleases: (E) EcoRI; (H) HindIII; (B) BamHI; (S) SphI; (T) TaqI; (A) ApaI; (V) EcoRV. Horizontal arrows indicate direction of transcription from promoters, as discussed in the text. $(\Delta)$ The insertion mutation in pap $B$, which constitutes the difference between pHMG15 and the wild-type derivative pHMG1. 

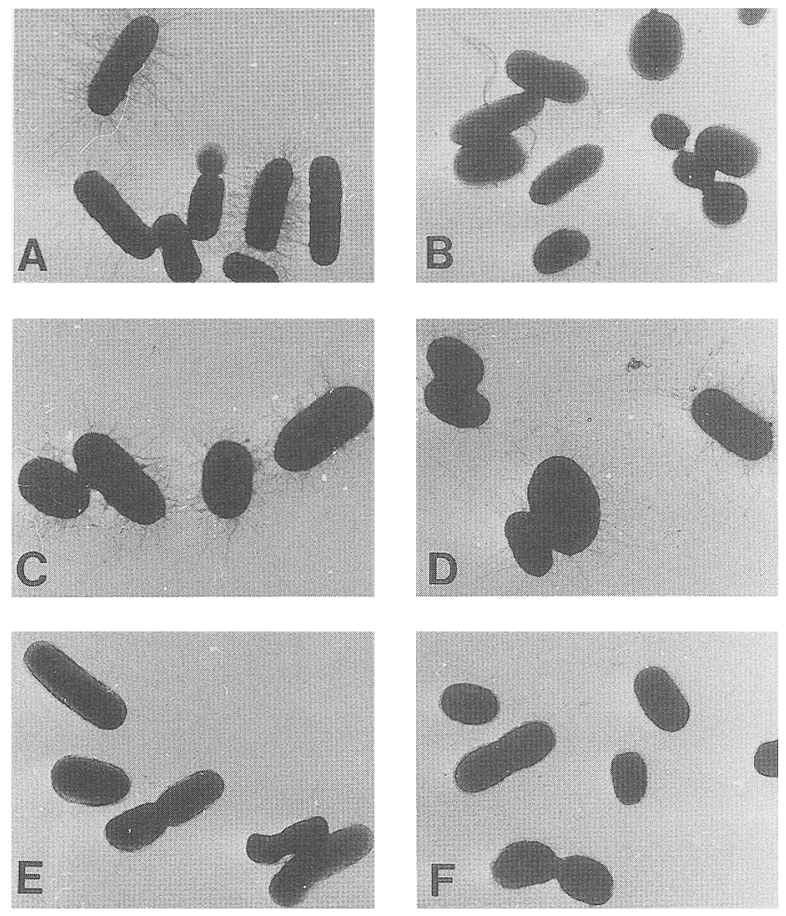

Figure 2. Electron microscopic analysis of pilus expression: (A) $\mathrm{HB} 101 / \mathrm{pPAP} 5$ at $37^{\circ} \mathrm{C} ;(B) \mathrm{HB} 101 / \mathrm{pPAP} 5$ at $26^{\circ} \mathrm{C}_{;}(\mathrm{C})$ $\mathrm{HB} 101 / \mathrm{pHMG} 93$ at $37^{\circ} \mathrm{C} ;(D) \mathrm{HB101} / \mathrm{pHMG} 93$ at $26^{\circ} \mathrm{C}_{;}(E)$ $\mathrm{HB} 101 / \mathrm{pBR} 322$ at $37^{\circ} \mathrm{C} ;(F) \mathrm{HB} 101 / \mathrm{pBR} 322$ at $26^{\circ} \mathrm{C}$.

the alaS gene. E. coli strain $\mathrm{HB} 101$ harboring the different plasmids was grown at $37^{\circ} \mathrm{C}$ and at $26^{\circ} \mathrm{C}$. The bacteria were then analyzed for production of pili by electron microscopy (Fig. 2) and for expression of hemagglutinating ability. As summarized in Table 1, the cloned wild-type pap genes (pPAP5) were temperature dependent in their expression, but the alaS promoter substitution (pHMG93) resulted in constitutive expression. The strain HB101/pHMG93 showed very similar numbers of pili per cell at the two temperatures, whereas no pili were seen on the surface of HB101/pPAP5 cells (only occasional flagella were observed) after growth at $26^{\circ} \mathrm{C}$ (Fig. 2). The fact that expression of hemagglutination by HB101/pHMG93 was also independent of growth temperature indicated that all the thermoregulatory effects on the pap genes were mediated by genes and/or sequences in the papI-papB region.

To determine whether or not the gene products of papB or papI were the direct cause of thermoregulation (e.g., as a thermolabile protein), we analyzed the expression of $\beta$-galactosidase from papA-lac $Z$ constructs (Fig. 1) with an intact or mutated papB gene (pHMGl, pHMG15) and from papB-lacZ operon fusions with intact or deleted papI genes (pPAP226, pPAP218). When tested at different temperatures $\left(25-37^{\circ} \mathrm{C}\right)$, the level of $\beta$-galactosidase expression was reduced, in all cases, at the lower temperature. Absence of either of the gene products from $p a p B$ or papI did not seem to abolish thermoregulation of $p a p B-p a p A$ transcription, although the steady-state level at $37^{\circ} \mathrm{C}$ was reduced by 10 -fold or
Table 1. Temperature-dependent and constitutive expression of Pap pilus adhesin

\begin{tabular}{lcccccc}
\hline & \multicolumn{2}{c}{$\begin{array}{c}c \\
\text { Pilus phenotype }\end{array}$} & & \multicolumn{2}{c}{$\begin{array}{c}\text { Adhesin } \\
\text { phenotype }\end{array}$} \\
\cline { 2 - 3 } \cline { 6 - 7 } Strain & $37^{\circ} \mathrm{C}$ & $26^{\circ} \mathrm{C}$ & & $37^{\circ} \mathrm{C}$ & $26^{\circ} \mathrm{C}$ \\
\hline HB101/pPAP5 & + & - & & + & - \\
HB101/pHMG93 & + & + & & + & + \\
HB101/pBR322 & - & - & & - & - \\
J96 & + & - & & + & - \\
J96/pHMG94 & + & + & & + & + \\
\hline
\end{tabular}

a Examined by electron microscopy.

b Mannose-resistant hemagglutination assay (MRHA).

more (M. Göransson, K. Forsman, B.E. Uhlin, unpubl.). Temperature-shift experiments (from $25-37^{\circ} \mathrm{C}$ ) with bacteria carrying the different fusion plasmids also showed that the kinetics of increase in $\beta$-galactosidase expression was similar (Fig. 3). These results suggested that the gene products from $p a p B$ and papI by themselves were not the cause of the temperature effect.

The $r p o H(h t p R)$ gene product of $E$. coli has been shown to activate transcription of a set of genes / the heat shock regulon) upon shifts from low to high growth temperatures while acting as an alternative $\sigma$-factor in the

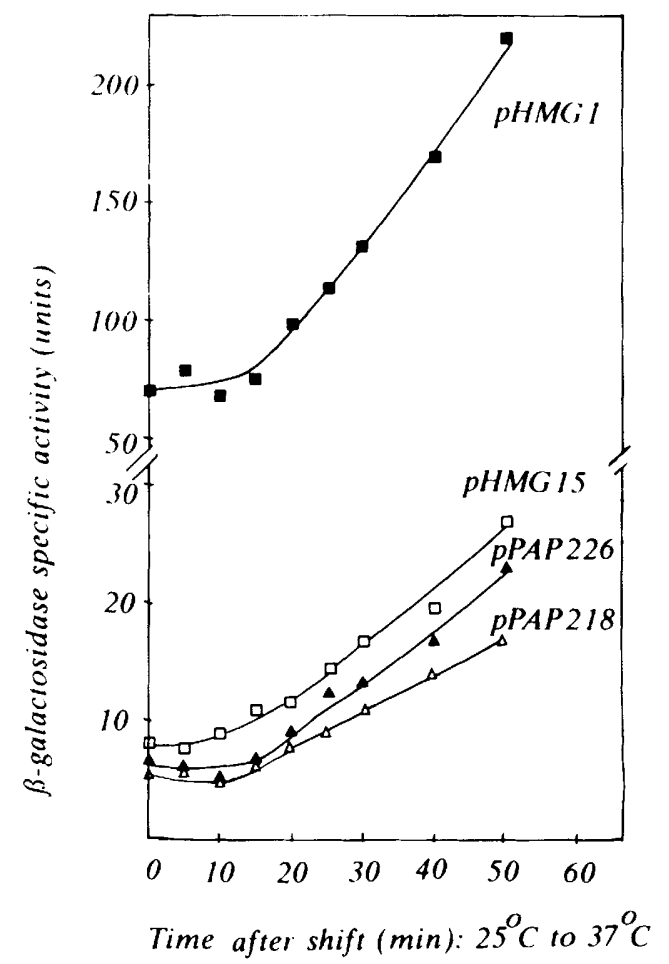

Figure 3. Expression of $\beta$-galactosidase by $\operatorname{pap} A-l a c Z$ and pap $B-l a c Z$ operon fusions during a temperature upshift. $E$. coli $\mathrm{K}-12$ strain $\mathrm{MC} 1029$ carrying the different plasmids was grown in $\mathrm{L}$ broth and shifted from $25^{\circ} \mathrm{C}$ to $37^{\circ} \mathrm{C}$, as indicated. Samples for measurements of $\beta$-galactosidase specific activity were taken at the indicated times. 
RNA polymerase complex (Grossman et al. 1984; Landick et al. 1984; Yura et al. 1984). To test directly for the possible involvement of the $r p o H$ gene product in the thermoregulation of pap gene transcription, we introduced papA-lacZ and papB-lacZ operon fusion plasmids into the $r p o H$ mutant $E$. coli strain $\mathrm{K} 165$ and its $\mathrm{rpoH}^{+}$parental strain SC122 (Cooper and Ruettinger 1975; Neidhardt and VanBogelen 1981). Although the strain $\mathrm{K} 165$ loses viability at $37^{\circ} \mathrm{C}$, we were able to monitor the expression of $\beta$-galactosidase from the fusion constructs during the initial cell doubling after a shift from $30-37^{\circ} \mathrm{C}$. The results from such an experiment with the papB-lacZ fusion plasmid pPAP218 are shown in Figure 4. Similar results were obtained with papAlacZ fusions (M. Göransson, K. Forsman, B.E. Uhlin, unpubl.). As observed with the $\mathrm{rpoH}^{+}$strain $\mathrm{MCl029}$ (Fig. 3 ), there was a gradual increase in $\beta$-galactosidase expression after shifts of cultures of the $r p o H$ mutant and wild-type derivatives of strain $\mathrm{SC} 122$. The results, therefore, did not provide any evidence that the heat shock $\sigma$-factor would be directly involved in thermoregulation of pap transcription.

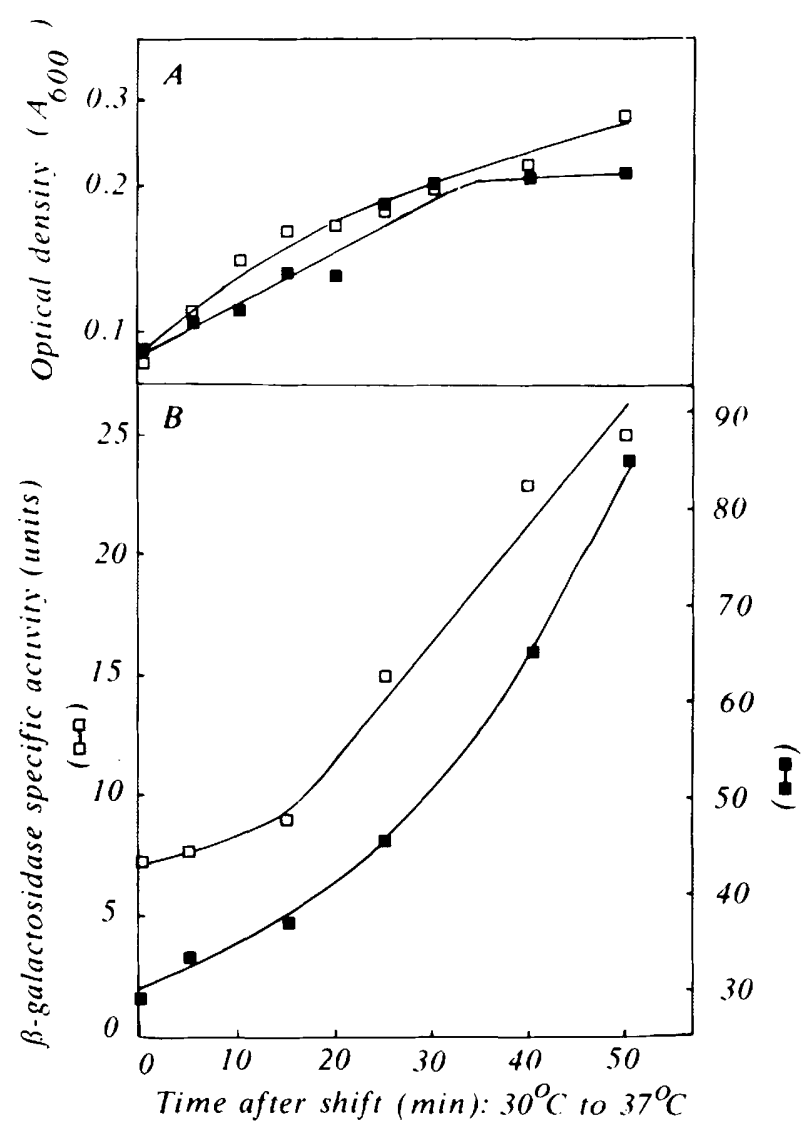

Figure 4. Effect of an $r p o H$ mutation on the $p a p B-l a c Z$ expression by plasmid pPAP2 18 during a temperature shift from $30^{\circ} \mathrm{C}$ to $37^{\circ} \mathrm{C}$. (A) Growth was monitored by optical density measurements. $(B) \beta$-Galactosidase expression. Open symbols represent strain SC122/pPAP218; closed symbols show strain K165/pPAP218.
Temperature-dependent transcription of the papI and papB operons

Our earlier studies indicated that the gene products of papB and papI act at the transcriptional level of expression of the pilin genes (Baåga et al. 1985, 1988; Göransson et al. 1988). Therefore, it seemed possible that the cellular level of one of these proteins might be temperature dependent and mediated the effect on papB$p a p A$ transcription. To confirm the papB-papA-lacZ operon fusion data and to determine whether or not the papI gene would be thermoregulated at the transcriptional level, we extracted RNA and performed Northern blot analysis after growth of strains HB101/pPAP5 and $\mathrm{J} 96$ at $37^{\circ} \mathrm{C}$ and $26^{\circ} \mathrm{C}$. The RNA blots were probed with a papI-specific probe and with a papA probe. The papA probe revealed both the 1300-nucleotide-long papBpapA-specific transcript and the 800-nucleotide-long papA-specific processed mRNA product (Båga et al. 1988). The RNA was also analyzed with a bla gene probe to utilize the $\beta$-lactamase gene of the vector plasmid as an internal control. The alteration in growth temperature appeared to have little effect on plasmid copy number, as revealed by the relative amounts of bla-specific mRNA produced (Fig. 5B). The bla gene in the vector pBR322 is transcribed from two different promoters, and there are three major terminators (von Gabain et al. 1983). One of the promoters (in the tet gene promoter region) was removed in the construction of pPAP5, consequently, there is less transcription of the bla gene in this plasmid. The steady-state levels of RNA-BA and RNA-A transcripts were very much reduced at $26^{\circ} \mathrm{C}$ in both the original E. coli $\mathrm{J} 96$ strain (Fig. $5 \mathrm{~A}$, lanes 2 and 3 ) and in strain $\mathrm{HB} 101$ carrying the cloned pap determinant (Fig. 5A, lanes 6 and 7). In addition to the temperature regulation of the papB-papA operon, the results also established that papI transcription was thermoregulated. As shown in Figure $5 \mathrm{C}$, the amount of papI mRNA was reduced at $26^{\circ} \mathrm{C}$ in a manner similar to that of the papB-papA transcripts. These results made it likely that the PapB and/or PapI proteins might be a limiting factor in transcription of the pilus adhesin operon at lower temperatures.

To test whether an increased cellular level of the gene products could possibly activate pap gene expression at lower temperatures, we constructed $\mathrm{papB}^{+}$and $\mathrm{papI}^{+}$ expression plasmids, in which the genes were put under the transcription of another promoter (Fig. 1). The plasmids pHMG79 and pHMG94 express the PapB and PapI proteins at high levels under the control of the lac promoter [lacP(UV5)], and we introduced these plasmids into the strain carrying the papA-lacZ operon fusion pHMGl and measured the effect on papA expression at $37^{\circ} \mathrm{C}$ and $26^{\circ} \mathrm{C}$ (Table 2). In the case of the papI expression plasmid, pHMG94, there was a clear stimulation of papA expression at both temperatures. The $\beta$-galactosidase level was even somewhat higher at $26^{\circ} \mathrm{C}$ than at $37^{\circ} \mathrm{C}$. These results suggested that high-level expression of papI could lead to temperature-independent expression. In contrast, the presence of pHMG79 led to only a 


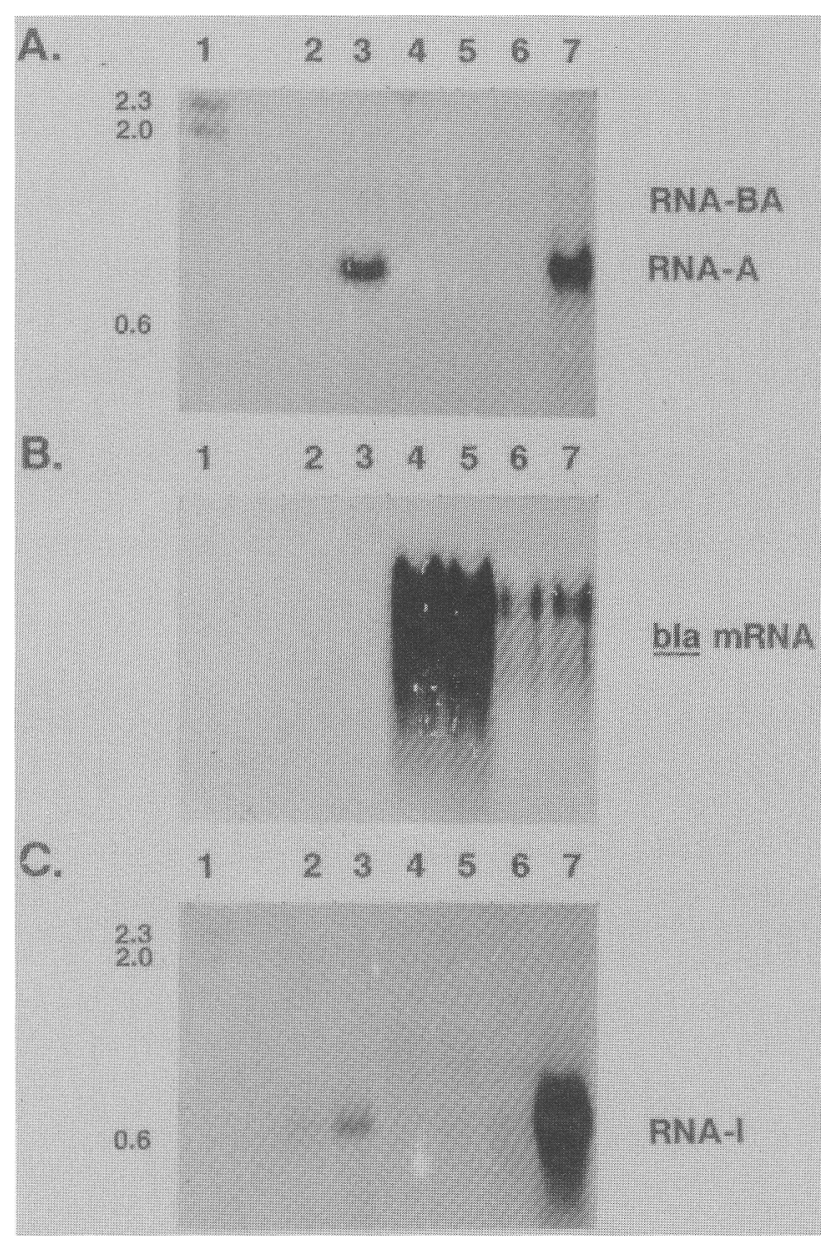

Figure 5. Northern blot hybridization analysis of papB and papI transcripts after growth at $26^{\circ} \mathrm{C}$ and $37^{\circ} \mathrm{C} .(A-C)$ Results after probing the RNA blots with papA-, bla-, and papI-specific probes, respectively. (Lane 1) Labeled DNA fragments of HindIIIdigested phage $\lambda$ DNA as molecular size markers. The RNA samples were 196 at $26^{\circ} \mathrm{C}$ (lane 2); 196 at $37^{\circ} \mathrm{C}$ (lane 3); $\mathrm{HB} 101$ / pBR322 at $26^{\circ} \mathrm{C}$ (lane 4 ); $\mathrm{HB} 101 / \mathrm{pBR} 322$ at $37^{\circ} \mathrm{C}$ (lane 5); $\mathrm{HB} 101 / \mathrm{pPAP} 5$ at $26^{\circ} \mathrm{C}$ (lane 6); HB101/pPAP5 at $37^{\circ} \mathrm{C}$ (lane 7 ). Strain $\mathrm{J} 96$ was grown in $\mathrm{L}$ broth, and the $\mathrm{HBI0l}$ derivatives were grown in the casamino acids medium. $(A, B)$ Results were obtained by probing the same blotted filter (Hybond-N) sequentially with a washing step in between, according to the procedure described by the manufacturer (Amersham International). The total amount of RNA on the gel used for the blot in $A$ and $B$ was $25 \mu \mathrm{g}$ in lanes 2 and 3 and $10 \mu \mathrm{g}$ in lanes $4-7 .(C)$ Results were obtained with a separate blot, and all lanes of the gel contained $50 \mu \mathrm{g}$ RNA samples.

slightly increased expression of $\beta$-galactosidase from pHMGl at $26^{\circ} \mathrm{C}$, there was an apparent decrease at $37^{\circ} \mathrm{C}$, and the level of $\beta$-galactosidase activity at both temperatures was only $\sim 20-25 \%$ of the papA-lac $Z$ expression from the pHMGl control strain at $37^{\circ} \mathrm{C}$ (Table 2).

The papI expression plasmid pHMG94 was also introduced into the E. coli isolate (strain J96) from which the pap DNA was cloned, and analysis of the phenotype showed that PapI overproduction resulted in temperature-independent expression of the native, chromosom-
Table 2. Effect of overproduction of PapB and PapI on papA-lacZ expression

\begin{tabular}{|c|c|c|c|}
\hline \multirow{2}{*}{$\begin{array}{l}\text { Fusion } \\
\text { plasmid }\end{array}$} & \multirow{2}{*}{$\begin{array}{l}\text { Coresiding } \\
\text { plasmid }\end{array}$} & \multicolumn{2}{|c|}{$\begin{array}{c}\beta \text {-Galactos- } \\
\text { idase sp. act. } \\
\text { (units) } \\
\end{array}$} \\
\hline & & $37^{\circ} \mathrm{C}$ & $26^{\circ} \mathrm{C}$ \\
\hline $\begin{array}{l}\text { pHMG1 (papI }{ }^{+}, \\
\text {papB } B^{+} \\
\text {papA-lacZ) }\end{array}$ & pACYC184(vector) & 293 & 12 \\
\hline pHMG1 & pHMG79|lacP(UV5)-papB $\left.B^{+}\right]$ & 54 & 74 \\
\hline pHMG1 & pHMG94[lacP(UV5)-papI $\left.I^{+}\right]$ & 390 & 490 \\
\hline $\begin{array}{l}\text { pHMG61 } \\
\quad(\text { alaS-lacZ) }\end{array}$ & - & 259 & 253 \\
\hline
\end{tabular}

ally located pilus adhesin genes (Table 1). Both pilus production and adhesion were fully expressed at $26^{\circ} \mathrm{C}$. Evidently, the biogenesis of functional pilus adhesins can occur at the lower growth temperature, and there did not appear to be any limitation at the level of translation or surface localization and interaction of the subunits. Taken together, the results suggested that the transcription of the gene for the activator PapI would be limiting in the thermoregulated wild-type situation.

\section{Discussion}

The expression of adhesive properties by bacteria appears to be regulated to fit the environmental circumstances. We have shown that the temperature-dependent expression of bacterial adhesion by digalactosidebinding $E$. coli is due to regulation at the transcriptional level. The polycistronic $p a p B$ operon and the monocistronic papI operon are divergently oriented, and transcription of both was essentially turned off at $26^{\circ} \mathrm{C}$, in comparison with $37^{\circ} \mathrm{C}$ (Fig. 5). The intact papB and papI genes were needed for high-level transcription of pilus adhesin genes (i.e., from the papB promoter) at $37^{\circ} \mathrm{C}$. The PapB protein was suggested recently to act as autoregulator of its own transcriptional unit, because overproduction in trans appeared to reduce expression of the $p a p B$ operon, and in vitro studies showed that the protein may bind to DNA sequences overlapping the papB promoter (K. Forsman, M. Göransson, and B.E. Uhlin, in prep.; see also Table 2). Depending on the cellular concentration, PapB would thereby have a dual role in activating and repressing transcription. The role of the papI gene has been less clear, but the present results showed that the PapI protein functioned as an activator of the pap $B$ operon. Furthermore, PapI appeared to be the limiting factor that became critical for pilus adhesin expression at low growth temperatures.

The best understood case of temperature regulation of bacterial gene expression is probably the heat shock regulon (Neidhardt 1987). The results of our experiments with an $r p o H$ mutant strain strongly suggested that the temperature regulation of pap transcription is a novel mechanism different from the heat shock regulon. The $\mathrm{RpoH} \sigma$-factor was not required; and in contrast to the 
transient induction of heat shock genes, the temperature-induced transcription of pap genes, upon a temperature upshift, resulted in a high steady-state level expression of pilus adhesins. It is interesting to note, however, that the PapI protein may play similar role as the $r p o H$ gene product in the sense that it functions as a temperature-regulated activator of some specific promoter|s|. The transcription of the $r p o H$ gene itself is temperature dependent, and the increased expression of the $\mathrm{RpoH}$ protein at higher temperatures accounts for the induction of mRNA synthesis from different genes of the heat shock regulon (Tilly et al. 1986; Erickson et al. 1987; Straus et al. 1987). The RpoH $\sigma$-factor thereby functions as an acceptor of the sensory information that is forwarded, by some unknown mechanism, in the cell upon a sudden change in temperature (Straus et al. 1987).

Whether or not PapI may interact with RNA polymerase, with the DNA for elsewhere), is not known at present, and we can only hypothesize about how papI gene transcription is regulated. In the case of $r p o H$, it was proposed that the induction occurs by a post-transcriptional derepression, i.e., by regulation of translation (Erickson et al. 1987). Furthermore, there appeared to be a transient increase in the stability of the protein upon heat shock (Straus et al. 1987). It has not been ruled out that the PapI activation could be affected by similar mechanisms. However, we find it more likely that the papI gene is regulated at the transcriptional level because we could increase its expression efficiently at low temperature by simply substituting its promoter. There was a low-level pap $B-l a c Z$ expression that showed temperature-dependent characteristics /e.g., kinetics during upshift similar to the wild-type case) even in a papI-deficient construct, pPAP218 (Fig. 3). This observation suggested that the intercistronic region between papl and pap $B$ in itself may have temperature-dependent properties. Furthermore, the Northern blot analysis established that the two transcriptional units from this region were temperature regulated to a similar extent (Fig. 5).

Pili-adhesin gene systems such as pap, which are associated with virulence of $E$. coli, represent additional genetic information not present in the genome of most (normal) intestinal E. coli populations. Often, a given clinical isolate of, e.g., uropathogenic E. coli, may carry several pilus adhesin determinants, and recent studies suggest that the DNA sequences corresponding to the $p a p I-p a p B$ region could be more conserved than the other regions (e.g., pilus subunit genes) among different adhesin determinants (Göransson et al. 1988).

Complementation tests with pap $B$ and papI mutants showed that the corresponding regulatory gene products of other gene systems can act in trans on Pap pili-adhesin expression. The PapI and PapB proteins may allow for regulatory interaction and coordination of expression of separate adhesin determinants according to the environmental circumstances. The role of PapI, as elucidated in this paper, would therefore include temperature regulation of several transcriptional units in such strains, and one may consider the multiple pilus adhesins to constitute a regulator network or regulon.

\section{Materials and methods}

Bacterial strains and plasmids, media, and growth conditions

The E. coli strains HB101 (Boyer and Roulland-Dussoix 1969) and MC1029 (Casadaban and Cohen 1980) were used as hosts of plasmids in most experiments. The uropathogenic E. coli isolate J96 was the strain from which the Pap pili-adhesin determinant was cloned initially (Hull et al. 1981). The strains K165 and SC122 /Cooper and Ruettinger 1975; Neidhardt and VanBogelen 1981) were utilized in tests of the possible influence by the $r p o H$ gene.

To obtain compatible combinations of plasmids in some experiments, the plasmid constructions were based on derivatives of either of the two cloning vectors, pBR322 (Bolivar et al. 1977) and pACYC184 (Chang and Cohen 1978). The pap-lacZ operon fusion plasmids pHMG1, pHMG15, pPAP218, and pPAP226 are all based on the vector pRZ5202 (Reznikoff and McClure 1986), and the constructions were reported previously (Göransson and Uhlin 1984; Båga et al. 1985). Cloning of a 1.4-kb EcoRI$B a m H I$ fragment carrying the alaS gene promoter (Putney et al. 1981) into EcoRI-BamHI-digested pRZ5202 gave plasmid pHMG61. The plasmid pPAP5 contains all of the pap genes within the EcoRI-BamHI fragment originating from $E$. coli strain 196. In pHMG93 the papI-papB control region of pPAP5 has been replaced by cloning of the alaS EcoRI-SalI promoter fragment from pHMG61 into EcoRI-XhoI-digested pHMG76 (Båga et al. 1988). The PapI expression plasmid pHMG94 was constructed in three steps. First a 275-bp papI-encoding SphITaqI fragment was cloned into AccI-SphI-digested pUC19 (Yanisch-Perron et al. 1985) to give plasmid pHMG96. Next, the BamHI-SphI papI fragment from pHMG96 was inserted behind the lacP(UV5) promoter in the BamHI-SphI-restricted expression vector pI)S300 (Sninsky et al. 1981). The resulting plasmid, pHMG95, was then digested with EcoRI-HincII, and the lacP(UV5)-papI+ fragment was cloned into EcoRI-PVuIIrestricted pACYC184 to give plasmid pHMG94. The PapB ex pression plasmid pHMG79 was constructed from pHMG72 (Båga et al. 1985). pHMG72 was made blunt-ended at its Apal site with T4 DNA polymerase and was then digested with $E c o$ RI. The papB promoter fragment was then replaced with an EcoRI-BamHI lacP(UV5) promoter fragment (blunt-ended at its $B a m H I$ end) derived from plasmid pJJS300. That plasmids pHMG79 and pHMG94 mediated high-level expression of the PapB and Papl proteins, respectively, was confirmed by gel elec trophoretic analysis of protein extracts of labeled minicell derivatives (data not shown).

Bacteria were routinely grown in L-broth or medium $E$ with $1.5 \%$ casamino acids, and solid media contained $1.5 \%$ agar, as described earlier (Göransson and Uhlin 1984; Båga et al. 1985; Göransson et al. 1988|.

\section{Recombinant DNA methods}

Plasmid constructions, transformation, DNA preparation, and analysis by agarose gel electrophoresis were carried out according to standard procedures (Maniatis et al. 1982). Restriction endonuclease digestions and DNA ligation reactions were carried out under the conditions recommended by the enzyme manufacturers (Boehringer-Mannheim $\mathrm{GmbH}$ and New England Biolabs).

\section{Determination of $\beta$-galactosidase activity}

The specific activity of $\beta$-galactosidase was assayed according to Miller (1972). Units were defined according to the following formula: 


$$
\text { Units }=1000 \times \frac{\mathrm{OD}_{420}-1.75 \times \mathrm{OD}_{550}}{t \times v \times \mathrm{OD}_{600}}
$$

Where $\mathrm{OD}_{420}$ and $\mathrm{OD}_{550}$ are read from the reaction mixture, $\mathrm{OD}_{600}$ reflects the cell density just before assay, $t$ is the time of the reaction in minutes, $v$ is the volume of culture used in the assay (in milliliters).

\section{Electron microscopy}

Bacterial suspensions in buffer $[10 \mathrm{~mm}$ Tris- $\mathrm{HCl}(\mathrm{pH} 7.5) ; 10$ mM magnesium chloride] were allowed to sediment on copper grids coated with thin films of $2 \%$ Formvar. After negative staining with $1 \%$ sodium silicotungstate $(\mathrm{pH} 6.0)$, the grids were examined in a JEOL 1003 microscope.

\section{Hemagglutination assay}

Tests of MRHA with human erythrocytes on glass slides were performed as described previously (Norgren et al. 1984).

\section{Northern blot analysis of $m R N A$}

Procedures for extraction of bacterial RNA and analysis by Northern blot hybridization were essentially as described previously (Båga et al. 1985, 1988). The buffer used was $20 \mathrm{~mm}$ sodium HEPES, $1 \mathrm{mM}$ EDTA, and $5 \mathrm{~mm}$ sodium acetate $1 \mathrm{pH}$ 7.0). The RNA was blotted onto a nylon filter (Hybond-N, Amersham International) and was cross-linked to the filter by irradiating with a UV-light illuminator. After hybridization, the filter was washed four times for $5 \mathrm{~min}$ at room temperature in $2 \times \operatorname{SSC} \mid 1 \times$ SSC contained $150 \mathrm{~mm} \mathrm{NaCl}, 15 \mathrm{~mm}$ sodium citratel, $0.5 \%$ SDS and, subsequently, during three $20-\mathrm{min}$ washes at $50^{\circ} \mathrm{C}$ in $0.1 \times$ SSC, $0.5 \%$ SDS. The M 13 phage clone used as papA-specific probe was labeled using a probe primer, as described previously (Båga et al. 1985). Purified DNA fragments employed as papI- and bla-specific probes were labeled with a multiprime DNA labeling system (Amersham International). The papI probe was a 275-bp SphI-TaqI fragment covering the gene. A 692-bp DraI fragment from pBR322 was used as a blaspecific probe.

\section{Acknowledgments}

We gratefully acknowledge the assistance by Lenore Johansson in the electron microscopy analysis. This work was supported by grants from the Swedish Natural Science Research Council (project B-BU1670), the Swedish Medical Research Council (project 16P-076677), and the National Swedish Board for Technical Development (project 84-5463).

\section{References}

Båga, M., M. Norgren, and S. Normark. 1987. Biogenesis of $E$. coli Pap pili: $\mathrm{PapH}$, a minor pilin subunit involved in cell anchoring and length modulation. Cell 49: 241-251.

Båga, M., M. Göransson, S. Normark, and B.E. Uhlin. 1985. Transcriptional activation of a Pap pilus virulence operon from uropathogenic Escherichia coli. EMBO J. 4:38873893.

- 1988. Processed mRNA with differential stability in the regulation of E. coli pilin gene expression. Cell 52: 197-206.

Bolivar, F., R.L. Rodriguez, P.J. Greene, M.C. Betlach, H.L. Heyneker, and H.W. Boyer. 1977. Construction and charac- terization of new cloning vehicles. II. A multipurpose cloning system. Gene 2: 95-113.

Boyer, H.W. and D. Roulland-Dussoix. 1969. A complementation analysis of the restriction and modification of DNA in Escherichia coli. J. Mol. Biol. 41: 459-472.

Casadaban, M.J. and S.N. Cohen. 1980. Analysis of gene control signals by DNA fusion and cloning in Escherichia coli. $I$. Mol. Biol. 138: 179-207.

Chang, A.C.Y. and S.N. Cohen. 1978. Construction and characterization of amplifiable multicopy DNA cloning vehicles derived from the P15A cryptic plasmid. I. Bacteriol. 134: $1141-1156$.

Cooper, S. and T. Ruettinger. 1975. A temperature-sensitive nonsense mutation affecting the synthesis of a major protein of Escherichia coli K-12. Mol. Gen. Genet. 139: 167176.

DeGraaf, F.K., F.B. Wientjes, and P. Klaasen-Boor. 1980. Production of K99 antigen by enterotoxigenic Escherichia coli strains of antigen groups 08,09,020, and 0101 grown at different conditions. Infect. Immun. 27: 216-221.

Erickson, J.W., V. Vaughn, W.A. Walter, F.C. Neidhardt, and C.A. Gross. 1987. Regulation of the promoters and transcripts of $r p o H$, the Escherichia coli heat shock gene. Genes Dev. 1: 419-432.

Göransson, M. and B.E. Uhlin. 1984. Environmental temperature regulates transcription of a virulence pili operon in $E$. coli. EMBO I. 3: 2885-2888.

Göransson, M., K. Forsman, and B.E. Uhlin. 1988. Functional and structural homology among regulatory cistrons of piliadhesin determinants in Escherichia coli. Mol. Gen. Genet. 212: $412-417$.

Grossman, A.D., J.W. Erickson, and C.A. Gross. 1984. The htpR gene product of $E$. coli is a sigma factor for heat-shock promoters. Cell 38: 383-390.

Hull, R.A., R.E. Gill, P. Hsu, B.H. Minshew, and S. Falkow. 1981. Construction and expression of recombinant plasmids encoding type 1 or D-mannose-resistant pili from a urinary tract infection Escherichia coli isolate. Infect. Immun. 33: 933-938.

Korhonen, T.K., V. Väisänen, H. Saxén, H. Hultberg, and S.B. Svenson. 1982. P-antigen-recognizing fimbriae from human uropathogenic Escherichia coli strains. Infect. Immunol. 37: 286-291.

Landick, R., V. Vaughn, E.T. Lau, R.A. VanBogelen, J.W. Erickson, and F.C. Neidhardt. 1984. Nucleotide sequence of the heat shock regulatory gene of $E$. coli suggests its protein product may be a transcription factor. Cell 38: 175-182.

Lund, B., F. Lindberg, B.-I. Marklund, and S. Normark. 1987. The PapG protein is the $\alpha$-D-galactopyranosyl-(1-4)- $\beta$-D-galactopyranose-binding adhesin of uropathogenic Escherichia coli. Proc. Natl. Acad. Sci. 84: 5898-5902.

Maniatis, T., E.F. Fritsch, and J. Sambrook. 1982. Molecular cloning. A laboratory manual. Cold Spring Harbor Laboratory, Cold Spring Harbor, New York.

Miller, J. 1972. Experiments in molecular genetics. Cold Spring Harbor Laboratory, Cold Spring Harbor, New York.

Mooi, F.R. and F.K. DeGraaf. 1985. Molecular biology of fimbriae of enterotoxigenic Escherichia coli. Curr. Top. Microbiol. Immunol. 118: 119-138.

Neidhardt, F.C. 1987. Multigene system and regulons. In Escherichia coli and Salmonella typhimurium cellular and molecular biology (ed. F.C. Neidhardt, J.L. Ingraham, K.B. Low, B. Magasanik, M. Schaechter, and H.E. Umbarger), pp. 1313-1317. American Society for Microbiology, Washington, D.C.

Neidhardt, F.C. and R.A. VanBogelen. 1981. Positive regulatory 
gene for temperature-controlled proteins in Escherichia coli. Biophys. Res. Commun. 100: 894-900.

Norgren, M., S. Normark, D. Lark, P. O'Hanley, G. Schoolnik, S. Falkow, C. Svanborg-Edén, M. Baåga, and B.E. Uhlin. 1984. Mutations in $E$. coli cistrons affecting adhesion to human cells do not abolish Pap pili fiber formation. EMBO $/$. 3: $1159-1165$

Normark, S., M. Båga, M. Göransson, F.P. Lindberg, B. Lund, M. Norgren, and B.E. Uhlin. 1986. Genetics and biogenesis of Escherichia coli adhesins. In Microbial lectins and agglutinins: Properties and biological activity (ed. D. Mirelman), pp. 113-143. Wiley, New York.

Ofek, I. and E.H. Beachey. 1980. General concepts and principles of bacterial adherence in animals and man. In $R e$ ceptors and recognition, Series B, Volume 6, Bacterial adherence (ed. E.H. Beachey), pp. 1-29. Chapman and Hall, London.

Putney, S.D., D. Ladage Meléndez, and P.R. Schimmel. 1981. Cloning, partial sequencing, and in vitro transcription of the gene for alanine tRNA synthetase. J. Biol. Chem. 256: 205211 .

Reznikoff, W.S. and W.R. McClure. 1986. E. coli promoters. In Maximizing gene expression (ed. W. Reznikoff and L. Gold), pp. 1-33. Butterworths, Boston.

Silverman, M., R. Belas, and M. Simon. 1984. Genetic control of bacterial adhesion. In Microbial adhesion and aggregation (ed. K.C. Marshall), pp. 95-107. Dahlem Conferenzen, Springer-Verlag, Berlin.

Sjöberg, B.-M., S. Hahne, M. Karlsson, H. Jörnvall, M. Göransson, and B.E. Uhlin. 1986. Overproduction and purification of the B2 subunit of ribonucleotide reductase from Escherichia coli. J. Biol. Chem. 261: 5658-5662.

Sninsky, J.J., B.E. Uhlin, P. Gustafsson, and S.N. Cohen. 1981. Construction and characterization of a novel two-plasmid system for accomplishing temperature-regulated, amplified expression of cloned adventitious genes in Escherichia coli. Gene 16: 275-286.

Straus, D.B., W.A. Walter, and C.A. Gross. 1987. The heat shock response of $E$. coli is regulated by changes in the concentration of $\sigma^{32}$. Nature 329: 348-351.

Svenson, S.B., H. Hultberg, G. Källenius, T.K. Korhonen, R. Möllby, J. Winberg. 1983. P-fimbriae of pyelonephritogenic Escherichia coli: Identification and chemical characterization of receptors. Infection 11: 61-67.

Tilly, K., J. Erickson, S. Sharma, and C. Georgopoulos. 1986 Heat shock regulatory gene $r p o H$ mRNA level increases after heat shock in Escherichia coli. J. Bacteriol. 168: 11551158.

Uhlin, B.E., M. Norgren, M. Båga, and S. Normark. 1985a. Adhesion to human cells by Escherichia coli lacking the major subunit of a digalactoside-specific pilus-adhesion. Proc. Natl. Acad. Sci. 82: 1800-1804.

Uhlin, B.E., M. Båga, M. Göransson, F.P. Lindberg, B. Lund, M. Norgren, and S. Normark. 1985b. Genes determining adhesin formation in uropathogenic Escherichia coli. Curr. Top. Microbiol. Immunol. 118: 163-178.

von Gabain, A., J.G. Belasco, J.L. Schottel, A.C.Y. Chang, and S.N. Cohen. 1983. Deacy of mRNA in Escherichia coli: Investigation of the fate of specific segments of transcripts. Proc. Natl. Acad. Sci. 80: 653-657.

Yanisch-Perron, C., J. Vieira, and J. Messing. 1985. Improved M13 phage cloning vectors and host strains: nucleotide sequences of the M13mp1 8 and pUC19 vectors. Gene 33:103119.
Yura, T., T. Tobe, K. Ito, and T. Osawa. 1984. Heat shock regulatory gene $(h t p R)$ of Escherichia coli is required for growth at high temperature but is dispensable at low temperature. Proc. Natl. Acad. Sci. 81: 6803-6807. 


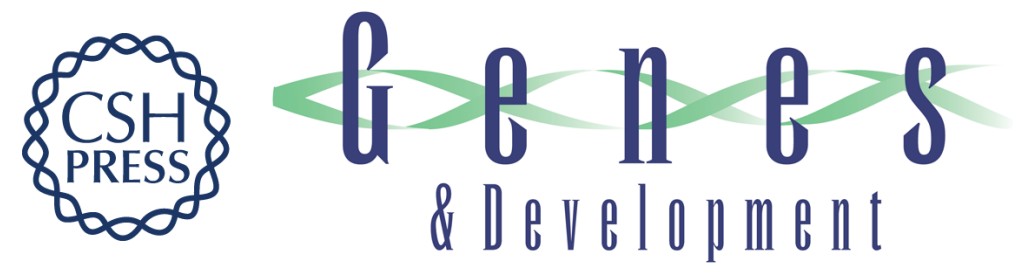

\section{Regulatory genes in the thermoregulation of Escherichia coli pili gene transcription.}

M Göransson, K Forsman and B E Uhlin

Genes Dev. 1989, 3:

Access the most recent version at doi:10.1101/gad.3.1.123

References This article cites 31 articles, 12 of which can be accessed free at:

http://genesdev.cshlp.org/content/3/1/123.full.html\#ref-list-1

License

Email Alerting

Service

Receive free email alerts when new articles cite this article - sign up in the box at the top right corner of the article or click here.

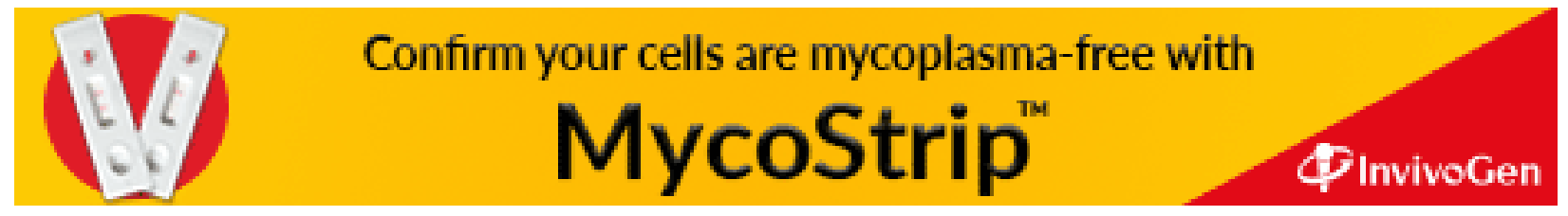

